\title{
HUBUNGAN KEBIASAAN KONSUMSI MAKANAN CEPAT SAJI DAN ASUPAN ENERGI DENGAN KEJADIAN OBESITAS PADA MAHASISWA YANG TINGGAL DI SEKITAR UNIVERSITAS MUHAMMADIYAH PAREPARE
}

\section{Relationship Between Fast Food Consumption Habits And Energy Intake With The Incidence Of Obesity In Students Living Around The Muhammadiyah Parepare University}

\author{
Nur Annisa Resky ${ }^{1}$, Haniarti $^{2}$, Usman $^{3}$ \\ ${ }^{1}$ Mahasiswa Fakultas Ilmu Kesehatan Universitas Muhammadiyah Parepare \\ ${ }^{2}$ Dosen Program Studi Kesehatan Masyarakat Universitas Muhammadiyah Parepare \\ ${ }^{3}$ Dosen Program Studi Kesehatan Masyarakat Universitas Muhammadiyah Parepare \\ (nannisaresky@gmail.com 082395458080)
}

\begin{abstract}
ABSTRAK
Obesitas merupakan akumulasi lemak abnormal atau berlebihan yang dapat mengganggu kesehatan yang disebabkan oleh asupan energi yang berlebih seperti karbohidrat, lemak dan protein. Mahasiswa cenderung mengkonsumsi makanan yang tinggi lemak seperti makanan cepat saji. Penelitian ini bertujuan untuk menjelaskan tentang hubungan kebiasaan konsumsi makanan cepat saji dan asupan energi dengan kejadian obesitas pada mahasiswa yang tinggal di sekitar Universitas Muhammadiyah Parepare. Metode penelitian yang digunakan adalah penelitian analitik dengan desain cross sectional. Data diperoleh dengan membagikan kuesioner kepada 99 mahasiswa yang di jadikan sampel mulai bulan Juli sampai Agustus 2018. Analisis penelitian yang digunakan adalah uji chi-square. Hasil penelitian menunjukkan bahwa ada hubungan yang signifikan antara kebiasaan konsumsi makanan cepat saji dan asupan energi dengan kejadian obesitas pada mahasiswa yang tinggal di sekitar Universitas Muhammadiyah Parepare. Bagi mahasiswa sebaiknya mengkonsumsi makanan yang bergizi dan beragam agar memiliki tubuh yang sehat, sehingga dapat mengikuti perkuliahan dengan baik.
\end{abstract}

Kata Kunci : Makanan cepat saji, asupan energi, obesitas

\section{ABSTRACT}

Obesity is abnormal or excessive fat accumulation that can interfere with health caused by excessive energy intake such as carbohydrates, fats and protein. Students tend to consume foods that are high in fat such as fast food. This study aims to explain the relationship between fast food consumption habits and energy intake with the incidence of obesity in students living around the Muhammadiyah Parepare University. The research method used is analytical research with cross sectional design. Date was obtained by distributing questionnaires to 99 students who were sampled from july to august 2018. The research analysis used was the chi-square test. The results of the study showed that there was a significant relationship between the habits of fast food consumption and energy intake with the incidence of obesity in students living in the vicinity of 
Muhammadiyah Parepare University. For students, they should consume nutritious and diverse fast food to have a healthy body so that they can take part in lectures.

Keywords:Fast food, energy intake, obesity 


\section{PENDAHULUAN}

\section{Pembangunan}

kesehatan

bertujuan untuk meningkatkan kualitas sumber daya manusia (SDM). Salah satu yang berperan dalam peningkatan kualitas SDM adalah gizi yang baik, terutama untuk peningkatan gizi remaja. Masalah gizi pada remaja muncul dikarenakan perilaku gizi yang salah, yaitu ketidakseimbangan antara konsumsi gizi dengan kecukupan gizi yang dianjurkan. Salah satu masalah gizi pada remaja adalah gizi lebih yaitu ditandai dengan berat badan yang relatif berlebihan bila dibandingkan dengan usia atau tinggi badan remaja sebaya, sebagai akibat terjadinya penimbunan lemak yang berlebihan dalam jaringan lemak tubuh.

Manusia yang sehat setiap harinya memerlukan makanan yang cukup, baik kualitas maupun kuantitasnya sehingga memiliki kesanggupan yang maksimal dalam menjalankan kehidupannya. Manusia harus memperoleh makanan yang cukup untuk memenuhi kebutuhan semua zat yang diperlukan untuk pertumbuhan, perbaikan dan pemeliharaan jaringan tubuh serta terlaksananya fungsi normal dalam tubuh. Selain itu, manusia mendapatkan makanan yang cukup untuk memperoleh energi yang cukup untuk memungkinkan manusia bekerja secara maksimal. ${ }^{1}$

Gaya hidup yang serba mudah dan santai yang membuat tubuh menjadi jarang bergerak atau menggunakan sedikit tenaga untuk aktivitas sehari-hari. Padahal dari makanan yang dikonsumsi, sebagian besarnya seharusnya dibakar agar tidak menumpuk menjadi lemak. Penumpukan lemak secara terus-menerus akan membuat ukuran tubuh menjadi terus bertambah. Ini tentu saja akan menambah pundi-pundi lemak di bawah kulit. $^{2}$

Remaja yang memiliki aktivitas seperti ini lebih memilih makanan cepat saji karena kelebihan yaitu penyajian cepat sehingga hemat waktu dan dapat dihidangkan kapan dan dimana saja, tempat saji dan penyajian yang higienis, dianggap makanan bergengsi, makanan modern, juga makanan gaul bagi anak muda. Makanan cepat saji yang dimaksud adalah jenis makanan yang dikemas, mudah disajikan, praktis, atau diolah dengan cara sederhana. ${ }^{3}$

Berdasarkan data Riskesdas 2013, prevalensi gizi lebih dan obesitas di Indonesa pada kelompok usia $>18$ tahun mencapai $28,9 \%$ menurut indeks massa tubuh (IMT). Berdasarkan World Health Organization (WHO) pada tahun 2015, 2,3 milyar orang dewasa akan mengalami overweight dan 700 juta yang 
mengalami obesitas. Prevalensi obesitas dan overweight di Indonesia sendiri juga masih tinggi. ${ }^{4}$

Di negara berkembang, jumlah anak remaja dengan overweight terbanyak berada di kawasan Asia yaitu $60 \%$ populasi atau sekitar 10,6 juta jiwa.

Di Indonesia sendiri prevelensi kelebihan berat badan pada penduduk di atas usia 18 tahun 2010 menunjukkan angka cukup tinggi. Terdapat 21,7\% penduduk di atas usia 18 tahun yang masuk golongan gemuk dan obesitas. Prevalensi kelebihan berat badan dan obesitas lebih banyak diderita oleh perempuan. Laki-laki memiliki prevalensi 16,3 sedangkan perempuan memiliki prevalensi 26,9. Sementara untuk prevalensi kurus sebesar 12,6. Dan prevalensi normal sebesar $65,8 .^{5}$

Universitas Muhammadiyah Parepare yang terletak di Jalan Jendral Ahmad Yani KM6 merupakan salah satu kampus swasta yang banyak diminati mahasiswa, memiliki kegiatan perkuliahan dan kegiatan organisasi yang cukup padat. Sehingga mahasiswanya memiliki peluang yang cukup besar untuk makan di luar rumah dan mengkonsumsi makanan jadi, dengan pola makan yang tidak seimbang.

Berdasarkan hasil pengamatan penulis mahasiswa Universitas
Muhammadiyah Parepare cenderung mengalami obesitas dikarenakan banyak mahasiswa yang jarang atau tidak pernah makan pagi (sarapan). Hal tersebut banyak terjadi dikarenakan jadwal kuliah cukup pagi, telat bagun tidur, malas untuk sarapan sehingga mahasiswa cenderung mengkonsumsi makanan cepat saji ketika menjelang siang hari karena kelebihan dari makanan cepat saji yaitu penyajian cepat sehingga hemat waktu dan dapat dihidangkan kapan dan dimana saja.

Tujuan penelitian ini adalah untuk mengetahui hubungan kebiasaan konsumsi makanan cepat saji dan asupan energi dengan kejadian obesitas pada mahasiswa yang tinggal di sekitar di Universitas Muhammadiyah Parepare.

\section{BAHAN DAN METODE}

Metode yang digunakan dalam penelitian ini adalah metode analitik dengan rancangan cross sectional study. Penelitian ini dilakukan di sekitar Universitas Muhammadiyah Parepare 20 April- 11 Agustus 2018. Populasi dalam penelitian adalah sebanyak 8891 orang. Untuk menentukan sampel digunakan rumus slovin. Variabel independen adalah makanan cepat saji dan asupan energi. Variabel dependennya adalah kejadian obesitas. 
Data primer adalah data yang diambil dari responden atau sampel penelitian. Adapun data diambil berupa data umur, berat badan, dan tinggi badan. Sedangkan data sekunder adalah data yang diambil dari Akademik Universitas Muhammadiyah Parepare yang berkaitan dengan jumlah mahasiswa di Universitas Muhammadiyah Parepare pada tahun 2017-2018. Pengolahan data dengan menggunakan komputer dengan Program Statistical Product and Service Solution (SPSS) versi 24.

\section{HASIL}

Hasil penelitian pada Tabel 1 menunjukkan karakteristik responden berdasarkan jenis kelamin yaitu perempuan sebanyak 75 responden atau $(75,8 \%)$ dan laki-laki sebanyak 24 responden atau (24,2\%). Karakteristik responden (Tabel 2) menunjukkan distribusi responden berdasarkan umur yaitu umur 17-20 tahun sebanyak 41 responden atau $(41,4 \%)$ dan umur 21-24 tahun sebanyak 58 responden atau $(58,6 \%)$. Karakteristik responden (Tabel 3) menunjukkan distribusi berdasarkan IMT yaitu normal sebanyak 27 responden atau $(27,3 \%)$ dan obesitas sebanyak 72 responden atau (72,7\%). Karakteristik responden pada tabel 4 menunjukkan distribusi berdasarkan konsumsi makanan cepat saji yaitu sering sebanyak 75 responden atau $(75,8 \%)$ dan jarang sebanyak 24 responden atau (24\%). Karakteristik responden pada tabel 5 menunjukkan distribusi berdasarkan asupan energi yaitu kurang sebanyak 0 responden atau (0\%), normal sebanyak 45 responden atau $(45,5 \%)$ dan lebih sebanyak 54 responden atau $(54,5 \%)$.

Hasil penelitian pada Tabel 6 menunjukkan hubungan konsumsi makanan cepat saji dengan kejadian obesitas pada mahasiswa yang tinggal di sekitar Universitas Muhammadiyah Parepare diperoleh hasil dari 75 responden yang sering mengkonsumsi makanan cepat saji ternyata 72 orang (72.8\%) diantaranya mengalami obesitas sedangkan responden yang sering mengkonsumsi makanan cepat saji berjumlah 3 orang (30.0) yang memiliki IMT normal.

Hasil uji statistic dengan menggunakan analisis Chi-square diperoleh nilai $\mathrm{p}=0,000$ dimana nilai $\mathrm{p}<0,05$, maka Ha diterima dan Ho ditolak, dapat diartikan bahwa ada hubungan antara konsumsi makanan cepat saji dengan kejadian obesitas pada mahasiswa yang tinggal disekitar Universitas Muhammadiyah Parepare.

Hasil penelitian pada Tabel 7 menunjukkan hubungan konsumsi asupan energy dengan kejadian obesitas 
pada mahasiswa yang tinggal di sekitar Universitas Muhammadiyah Parepare diperoleh hasil dari 99 responden yang memiliki asupan energi lebih sebanyak 54 orang $(54,5 \%)$ diantaranya mengalami obesitas sedangkan responden yang memiliki asupan energi normal yang mengalami obesitas sebanyak 18 orang (18.2).

Hasil uji statistic dengan menggunakan analisis Chi-square diperoleh nilai $\mathrm{p}=0,000$ dimana nilai $\mathrm{p}<0,05$, maka Ha diterima dan Ho ditolak, dapat diartikan bahwa ada hubungan antara asupan energi dengan kejadian obesitas pada Mahasiswa yang tinggal di sekitar Universitas Muhammadiyah Parepare.

\section{PEMBAHASAN}

Hasil yang didapatkan dari penelitian ini yaitu responden sering mengkonsumsi makanan cepat saji sehingga mereka mengalami obesitas, dikarenakan makanan cepat saji mengandung kalori yang tinggi. Konsumsi yang tinggi terhadap makanan cepat saji dapat menyebabkan terjadinya gizi lebih atau kegemukan (Obesitas). Karena kandungan dari makanan cepat saji tersebut tinggi kalori, tinggi lemak dan rendah serat. Kebiasaan responden sering mengkonsumsi makanan cepat saji disebabkan karena responden tidak sarapan pada pagi hari sehingga menjelang siang hari mereka cenderung mengkonsumsi makanan cepat saji seperti bakso, mie instan dan gorengan. Selain itu padatnya jadwal kampus, malas masak, dan berkumpul dengan teman menyebabkan mereka lebih memilih makanan cepat saji. Kebiasaan tersebut cenderung dilakukan oleh responden yang bertempat tinggal tidak dengan orang tua (kost). Kehadiran makananan cepat saji dalam industri makanan di Indonesia sangat mempengaruhi pola makan khususnya di perkotaan, harga yang terjangkau, cepat dan mudah di dapatkan, jenis makanannya sesuai selera menjadi daya tarik sehingga mahasiswa cenderung lebih memilih makanan cepat saji.

Hasil penelitian ini sejalan dengan penelitian Damopoli dkk $(2013)^{6}$, begitu juga dengan penelitian yang dilakukan oleh Myhre (2013) ${ }^{7}$ yang menyatakan bahwa mengkonsumsi makanan di restoran (diluar rumah) memiliki kandungan gizi yang rendah terutama serat dan tinggi kalori serta gula karena termasuk makanan cepat saji sehingga menyebabkan konsumen mengalami gizi lebih bahkan obesitas.

Dalam penelitian ini, responden sering mengkonsumsi makanan cepat 
saji sehingga mereka mengalami obesitas, dikarenakan makanan cepat saji mengandung kalori yang tinggi. Konsumsi yang tinggi terhadap makanan cepat saji dapat menyebabkan terjadinya gizi lebih atau kegemukan (Obesitas). Saat ini, pola makan masyarakat kita, terutama yang tinggal di kota-kota besar telah mengalami pergeseran. Mereka cenderung tidak mau mengkonsumsi makanan tradisional seperti gado-gado yang kaya serat dan gizi serta rendah kalorinya. $^{8}$

Hal ini membuktikan bahwa Mereka cenderung tidak mau mengkonsumsi makanan tradisional seperti gado-gado yang kaya serat dan giizi rendah kalorinya. Makanan cepat saji memenuhi persyaratan bagi kehidupan modern karena cara penyajiannya yang cepat sehingga mahasiswa yang sibuk dengan kegiatannya bisa memesan makanan cepat saji dan memakannya sambil berdiri atau berjalan. Mereka juga dapat menikmati makanan cepat saji di tamantaman di tengah kota sambil bersantai. Makanan cepat saji modern adalah jenis makanan yang mudah disajikan, praktis dan umumnya diproduksi oleh industry pengolahan pangan dengan teknologi tinggi dan memberikan berbagai zat aditif untuk mengawetkan dan memberikan cita rasa bagi produk tersebut. ${ }^{9}$

Restoran makanan cepat saji merupakan tempat yang tepat untuk bersantai. Zaman modern membawa perubahan besar dalam kehidupan yang menjadikan makanan siap saji sebagai salah satu pilihan menu makanan. Perubahan pola makan dari pola makan tradisional ke pola makan modern yang dapat menimbulkan mutu gizi yang tidak seimbang, Pola makan praktis dan siap saji terutama di perkotaan dan jika dikonsumsi secara tidak rasional akan menyebabkan kelebihan masukan kalori yang akan menimbulkan obesitas.

Mahasiswa memiliki kebiasaan yang sangat sulit untuk ditinggalkan yaitu kebiasaan jajan makanan yang mana jajanan makanan tersebut tidak memenuhi gizinya. Makanan cepat saji tidak harus dihindari akan tetapi dibatasi. Tidak dikonsumsi setiap hari, tetapi sebaiknya cukup sekali atau 2 kali sebulan. Ketidakseimbangan gizi dalam tubuh terjadi karena makanan cepat saji dijadikan sebagai pola makan setiap hari. Kelebihan kalori, lemak dan natrium akan terakumulasi di dalam tubuh sehingga dapat menimbulkan berbagai penyakit seperti tekanan darah tinggi, jantung koroner serta obesitas. Mahasiswa cenderung kurang melakukan olahraga sehingga 
menyebabkan tubuhnya kurang mengeluarkan energi yang menyebabkan mudah mengalami obesitas. Jenis makanan cepat saji yang paling disukai oleh responden adalah Mie Instan, Bakso, Gorengan dengan frekuensi 3-4 kali/minggunya.

\section{KESIMPULAN DAN SARAN}

Berdasarkan hasil penelitian yang telah dilakukan bahwa ada hubungan antara kebiasaan konsumsi makanan cepat saji dengan kejadian obesitas pada mahasiswa yang tinggal di sekitar Universitas Muhammadiyah Parepare (P value $=0,000)$ dan ada hubungan antara asupan energi dengan kejadian obesitas pada mahasiswa yang tinggal di sekitar Universitas Muhammadiyah Parepare (Pvalue =0,000). Dari kesimpulan tersebut disarankan Bagi mahasiswa yang tinggal disekitar kampus sebaiknya mengkonsumsi makanan yang bergizi dan beragam agar memiliki tubuh yang sehat, sehingga dapat mengikuti perkuliahan dengan baik dan Sebaiknya mahasiswa yang tinggal disekitar kampus memiliki waktu makan yang teratur sehingga menjadi mahasiswa kesehatan yang baik pula dan selanjutnya dapat mempersiapkan diri dengan lebih baik lagi menjadi generasi yang memiliki sumber daya manusia yang berkualitas karena kesehatan adalah salah satu faktor yang sangat penting untuk mencapai sumber daya manusia yang berkualitas.

\section{DAFTAR PUSTAKA}

1. Sulistyoningsih, H. Gizi Untuk Kesehatan Ibu dan Anak, Yogyakarta: Graha Ilmu; 2011.

2. Dewi, L. Pola Makan Sehat dan Gaya Hidup yang benar. 2011. [Serial Online] diakses 18 Maret 2018 pada http://www.rumahsakitmitrakemayor an.com.

3. Lutfi, S. Makan Teratur Mahasiswa Tingkat Akhir. 2011. [Serial Online] diakses 18 Maret 2018 pada http://lutiblurry.com.

4. Kementrian Kesehatan RI. Buku Riskesdes 2013 dalam Angka. Jakarta: Badan Penelitian dan Pengembangan Kesehatan RI; 2013.

5. Depkes RI. Riset Kesehatan Dasar (RISKESDAS). Laporan Nasional Badan Penelitian dan Pengembangan Kesehatan Departemen Kesehatan Republik Indonesia; 2010.

6. Damopolii. W, dkk. Hubungan Konsumsi Fast Food dengan Kejadian Obesitas Pada Anak SD Di Kota Manado: Program Studi Ilmu Keperawatan Fakultas Kedokteran Universitas Sam Ratulangi; 2013. 
7. Myhre B.J, Loken B.E, Wandel M dan Andersen F.L. 2013. Eating Location is Associated With the Nutritional Quality of the diet in Norwegian Adults. Public Health Nutrition.

8. Syamhudi. Perubahan Pola Makan Timbulkan berbagai Penyakit yang
Berdampak Kematian; 2011. [Serial

Online] diakses 18 Maret 2018 pada http://www.mediaprofesi.com.

9. Almatster S. Gizi Seimbang dalam Daur Kehidupan. Jakarta: PT Gramedia Pustaka Utama; 2011. 


\section{LAMPIRAN}

Tabel 1. Distribusi responden berdasarkan jenis kelamin mahasiswa yang tinggal di sekitar Universitas Muhammadiyah Parepare

\begin{tabular}{ccc}
\hline Jenis Kelamin & Frekuensi & Persen (\%) \\
\hline Perempuan & 75 & 75,8 \\
Laki-Laki & 60 & 24,2 \\
\hline Total & 100 & 100 \\
\hline
\end{tabular}

Tabel 2. Distribusi responden berdasarkan umur mahasiswa yang tinggal di sekitar Universitas Muhammadiyah Parepare

\begin{tabular}{ccc}
\hline Pendidikan & Frekuensi & Persen (\%) \\
\hline $17-20$ & 41 & 41,4 \\
$21-24$ & 58 & 58,6 \\
\hline Total & 100 & 100 \\
\hline
\end{tabular}

Tabel 3. Distribusi responden berdasarkan IMT mahasiswa yang tinggal di sekitar Universitas Muhammadiyah Parepare

\begin{tabular}{ccc}
\hline IMT & Frekuensi & Persen (\%) \\
\hline Normal & 27 & 27,3 \\
Obesitas & 72 & 72,7 \\
\hline Total & 100 & 100 \\
\hline
\end{tabular}

Tabel 4. Distribusi responden berdasarkan konsumsi makanan cepat saji mahasiswa yang Tinggal di sekitar Universitas Muhammadiyah Parepare

\begin{tabular}{ccc}
\hline IMT & Frekuensi & Persen $(\%)$ \\
\hline Sering & 75 & 75,8 \\
Jarang & 24 & 24,2 \\
\hline Total & 100 & 100 \\
\hline
\end{tabular}

Tabel 5. Distribusi responden berdasarkan asupan energi mahasiswa yang tinggal di sekitar Universitas Muhammadiyah Parepare

\begin{tabular}{ccc}
\hline IMT & Frekuensi & Persen $(\%)$ \\
\hline Normal & 27 & 27,3 \\
Obesitas & 72 & 72,7 \\
Lebih & 54 & 54,5 \\
\hline Total & 100 & 100 \\
\hline
\end{tabular}


Tabel 6. Hubungan konsumsi makanan cepat saji dengan kejadian obesitas pada mahasiswa yang tinggal di sekitar Universitas Muhammadiyah Parepare

\begin{tabular}{|c|c|c|c|c|c|c|c|c|}
\hline \multirow{3}{*}{$\begin{array}{l}\text { Konsumsi } \\
\text { Makanan } \\
\text { Cepat Saji }\end{array}$} & \multicolumn{4}{|c|}{ IMT } & \multicolumn{2}{|c|}{ Jumlah } & \multirow{3}{*}{ P Value } & \multirow{3}{*}{ A } \\
\hline & \multicolumn{2}{|c|}{ Normal } & \multicolumn{2}{|c|}{ Obesitas } & \multirow[b]{2}{*}{$\mathrm{n}$} & \multirow[b]{2}{*}{$\%$} & & \\
\hline & $\mathrm{n}$ & $\%$ & $\mathrm{n}$ & $\%$ & & & & \\
\hline Sering & 3 & 3.0 & 72 & 72.7 & 75 & 75.8 & & \\
\hline Jarang & 24 & 24.2 & 0 & 0 & 24 & 24.2 & 0.000 & 0.005 \\
\hline Total & 27 & 27.3 & 72 & 72.7 & 99 & 100.0 & & \\
\hline
\end{tabular}

Tabel 7. Hubungan Asupan Energi dengan Kejadian Obesitas pada Mahasiswa yang tinggal di sekitar Universitas Muhammadiyah Parepare

\begin{tabular}{|c|c|c|c|c|c|c|c|c|}
\hline \multirow{3}{*}{$\begin{array}{l}\text { Asupan } \\
\text { Energi }\end{array}$} & \multicolumn{2}{|c|}{ IMT } & \multicolumn{4}{|c|}{ Jumlah } & \multirow{3}{*}{$\begin{array}{c}\mathrm{P} \\
\text { Value }\end{array}$} & \multirow{3}{*}{ A } \\
\hline & \multicolumn{2}{|c|}{ Normal } & \multicolumn{2}{|c|}{ Obesitas } & \multirow[b]{2}{*}{$\mathrm{n}$} & \multirow[b]{2}{*}{$\%$} & & \\
\hline & $\mathrm{n}$ & $\%$ & $\mathrm{n}$ & $\%$ & & & & \\
\hline Normal & 27 & 27.3 & 18 & 18.2 & 45 & 45.5 & & \\
\hline Lebih & 0 & 0 & 54 & 54.5 & 54 & 54.5 & 0.000 & 0.005 \\
\hline Total & 27 & 27.3 & 72 & 72.7 & 99 & 100.0 & & \\
\hline
\end{tabular}

